\title{
ASSESSMENT OF GENETIC VARIATION OF PEARL OYSTER, Pinctada maxima, BASED ON THE ANALYSIS OF MITOCHONDRIAL CYTOCHROME OXIDASE SUBUNIT I GENE
}

\author{
Achmad Sudradjat ${ }^{*}$ \#, Rini Susilowati*), and Imron ${ }^{* * *}$ \\ *) Research Center for Aquaculture. JI. Ragunan 20, Pasar Minggu, J akarta Selatan 12540 \\ ${ }^{*}$ Research Center for Marineand Fisheries Product Processing and Biotechnology \\ JI. KS. Tubun Petamburan VI, J akarta Pusat 10260, Slipi, Petamburan, Jakarta \\ ${ }^{* * *}$ Research Institute for Freshwater Fish Breeding and Aquaculture \\ JI. Raya 2 Sukamandi, Subang 41256
}

\begin{abstract}
Pearl oyster, Pinctada maxima is one of economically important species in aquaculture, particularly in pearl industry. Information on genetic variation of pearl oyster is required in order to be able to make a sound management of it's natural populations and to utilize it to improve the quality of pearl culture. Five populations from different geographic locations of pearl oyster, Pinctada maxima, (Sumbawa, Bali, Selat Sunda, Belitung, and South Sulawesi) were analyzed for genetic variation within a 750-base pair region of the Mitochondrial Cytochrome Oxidase subunit I (MtCOI) gene using Restriction Fragment Length Polymorphism (RFLP) technique. The analysis of 25 pearl oyster samples, their haplotype diversity ranged from 0.0970 to 0.1939 and the number of haplotype in each population ranged from three to five haplotypes. Clustering of populations based on Nei's genetic distances and constructed using unweighted pair-group method with Arithmetic mean (UPGMA) showed that the populations were clustered into two groups: Belitung, Selat Sunda, Bali and Sumbawa in one group, while South Sulawesi in the second group.
\end{abstract}

\section{KEYWORDS: genetic variation, pearl oyster, Mitochondrial Cytochrome} oxidase I (MtCO I)

\section{INTRODUCTION}

Pearl oyster or the silver- lipped oyster, Pinctada maxima is common to South East Asia and North Australia. It is one of the important species in pearl industry. The high market demand on pearl has stimulated the increase of pearl culture practices in Indonesia, which subsequently leads to the increase of seeds demand. According to Elliot (2000), four types of input management were required to increase aquaculture production, namely (1) farm size,
(2) facility and infrastructure, (3) feed, and (4) genetics. The first three components are related with the environment and aquaculture technology while the last one is related with biological potentials of the species in utilizing their environmental conditions. The aims of exploitation of biological potential of pearl oyster have been to perform genetic improvement program aiming to increase the production of pearl oyster through manipulation of genetic variation of broodstock. Genetic

\# Corresponding author. Research Center for Aquaculture. Jl. Ragunan 20, Pasar Minggu, Jakarta Selatan 12540, Indonesia. Tel.: +62 217815052

E-mail address: 
improvement could be conducted through several methods, among which are selective breeding and crossbreeding (Tave, 1986).

Selection and breeding program for stock management of pearl oyster require basic information regarding the genetic potentials of the species of interest which can be gathered from the information of genetic distance and haplotype diversity (Appleyard \& Ward, 2006). Information on genetic variation and genetic distance can be used to increase genetic variation of stocks through interpopulation hybridisation. The improved genetic quality of broodstock is expected to be capable of producing high quality seeds which have better survival, growth and environmental adaptability.

One of the common methods to describe genetic variation has been the use of mitochondrial DNA marker, particularly the region of cytochrome oxidase subunit I (COI) gene, using restriction fragment length polymorphisms (RFLP) technique. The gene region was selected on the ground that its evolutionary rate is brief. This technique analyzes genetic variation of populations based on the differences in fragment length of DNA amplified by polymerase chain reaction (PCR) following digestion by restriction enzymes (Hansen et al., 1997). Typical patterns of restriction fragments both within and between populations can be used to describe genetic variation and genetic divergences among populations.

This study was aimed to describe the genetic variation of Indonesian pearl oyster populations (Sumbawa, Bali, Selat Sunda, Belitung, and South Sulawesi) and their phylogenetic relationships using MtCOI as molecular marker. The availability of this information may serve as a standing point for sustainable management of both natural populations and captive broodstock in aquaculture.

\section{MATERIALS AND METHODS}

Twenty five samples of pearl oyster of 10$30 \mathrm{~cm}$ long in size were collected during May to December 2007. They were originated from five locations, namely Panjang Island, Sumbawa (SB); Gilimanuk Strait, Bali (BA); Handeuleum Island, Sunda strait (SS); Ru Strait, Belitung (BL); and Awerange gulf, South Sulawesi (SL).
Genetics analysis using mtDNA RFLP technique was conducted from February to June 2008 at the genetic laboratory of Research Institute for Fresh water Fish Breeding and Aquaculture, Sukamandi.

Mitochondrial DNA analysis consisted of a series of steps namely genomic DNA extraction, PCR amplification, endonuclease digestion, and visualization. Genomic DNA extraction was performed by grounding and homogenizing of approximately $20 \mathrm{mg}$ muscle tissue and put it into $1.5 \mathrm{~mL}$ centrifuge tube containing $250 \mathrm{uL}$ of cell lysis solution (10 uL Tris $\mathrm{pH}$ 8, 10 mM EDTA pH 8; 2\%SDS). Following the addition of 5 ul protein kinase, the mixture was incubated at $55^{\circ} \mathrm{C}$ for $4-24$ hours. Following this step, $250 \mathrm{~mL}$ of ammonium acetate was added and the mixture was shaken vigorously for five minutes, let it in room temperature for 15 minutes and cooled at $4^{\circ} \mathrm{C}$ for 10 minutes. The next step was protein precipitation, which was done by spinning at $13000 \mathrm{rpm}$ for 10 minutes. The supernatant was moved into a new tube in which two volumes of $100 \%$ ethanol were added, followed by spinning for 5 minutes. Ethanol was discarded and the pellet was washed with $70 \%$ ethanol and spinning 13000 rpm for 3 minutes. After decanting of the ethanol, the DNA pellet was resuspend in $50 \mathrm{~mL}$ of T10E0.1 buffer an incubated at $65^{\circ} \mathrm{C}$ forl hour.

Mitochondrial DNA amplification was carried out using Mycycler thermal cycler (Biorad). The thermal profile for the PCR was initial denaturation at $94^{\circ} \mathrm{C}$ for 1 minute, followed by 30 cycles of denaturation at $94^{\circ} \mathrm{C}$ for 1 minute, annealing at $45^{\circ} \mathrm{C}$ for 1 minute, extension at $72^{\circ} \mathrm{C}$ for 1 minute, and terminated with final extension at 72 for 5 minutes. PCR reaction was conducted in PCR tubes containing 13.6 of $\mathrm{mL} \mathrm{dH_{2 }}$ O, $5 \mathrm{~mL}$ of $10 \times$ Buffer; $1.5 \mathrm{~mL}$ of $25 \mathrm{mM}$ of $\mathrm{MgCl}_{2} ; 0.5 \mathrm{~mL}$ of $2.5 \mathrm{mM}$ dNTP; $1.6 \mathrm{~mL}$ of 10 pM of each primer; 1 unit Taq-DNA polymerase and $1 \mathrm{~mL}$ of genomic DNA. The primers used were (COI) forward: 5' - ATA ATG ATA GGA GGR TTT GG- 3' and reverse: 5'- GCT CGT GTR CTA CRT CCA T- 3' (Williams \& Benzie, 1997). The amplified DNA was digested with endonucleases following manufacturer's protocol. The restriction fragments were then resolved in 3\%agarose gel run with Tris- BoricEDTA (TBE) buffer. The products were then visualized using ultra violet (UV) light in a gel documentation system. 
Intrapopulation genetic variation and interpopulation genetic divergence were measured using haplotype diversity (Nei, 1987) and genetic distance (Reynolds et al., 1983), respectively. Dendrogram of phylogenetic relationship among populations was constructed using Unweighted Pair Group Method by Arithmetic mean (UPGMA) (Bermingham, 1990). All analyses were implemented in tools for population genetic analysis (TFPGA) program.

\section{RESULTS AND DISCUSSION}

PCR amplification of mtCOI gene resulted in DNA fragments of $750 \mathrm{bp}$ long. The fragments of this size were found in all investigated populations. Digestion of the fragments with three restriction enzymes, namely Fokl, Hae III, and NlaIV, yielded polymorphic restriction patterns. Seven restriction fragments were identified, namely $A, B$, and $C$ restriction fragments for Fok $I$, and $A$ and $B$ restriction fragments for both Hae III and NlaIV. The length of these restriction fragments were comparable to those obtained by Susilowati et al. (2008) in other Pinctada species, namely P. Margaritifera.
Overall, ten composite haplotypes were identified. The number of composite haplotypes found within the respective population ranged from three to four. Based on the occurrence within population, three types of composite haplotypes could be identified, namely common, partially shared and specific composite haplotypes. The composite haplotypes AAA was found and predominance in Sumbawa (20\%), Bali $(30 \%$, Sunda Strait (30\%), and Belitung $(20 \%)$, while its proportion in the population of South Sulawesi was 10\%(Table 1 ). The figures in Table 1 also shows that the composite haplotype of AAA was the only common haplotype since it was the only composite haplotype found in all population and it could indicate the similarity in the pearl oyster stocks.

Three composite haplotypes, namely BAA, $A B A$, and CAA could be categorized as partially shared since they existed in more than one but not in all populations. The first composite haplotype (BAA) for instance, existed in the Sumbawa and South Sulawesi populations, while the second composite haplotype (ABA) existed in the Sumbawa and Bali and the third composite haplotype (CAA) existed in the

Table 1. Frequency distribution and composite haplotype within each of five populations of pearl oyster, Pinctada maxima

\begin{tabular}{ccccccc}
\hline $\begin{array}{c}\text { Composite } \\
\text { haplotype }\end{array}$ & Total & SB & BA & SS & BL & SL \\
\hline AAA & 11 & 0.2 & 0.3 & 0.3 & 0.2 & 0.1 \\
BAA & 2 & 0.1 & - & - & - & 0.1 \\
ABA & 3 & 0.2 & 0.1 & - & - & - \\
CAA & 2 & - & - & 0.1 & - & 0.1 \\
CAB & 2 & - & - & - & - & 0.2 \\
BAB & 1 & - & 0.1 & - & - & - \\
AAB & 1 & - & - & - & 0.1 & - \\
ABB & 1 & - & - & - & 0.1 & - \\
BBA & 1 & - & - & - & 0.1 & - \\
CBA & 1 & - & - & 0.1 & - & - \\
\hline Number of samples & 25 & 5 & 5 & 5 & 5 & 5 \\
\hline Number of haplotype & & 3 & 3 & 3 & 4 & 4 \\
\hline Haplotype diversity & & 0.1185 & 0.097 & 0.1239 & 0.1832 & 0.1939 \\
\hline
\end{tabular}

Remarks:

SB: Sumbawa, BA: Bali, SS: Sunda Strait, BL: Belitung, SL: South Sulawesi 
South Sulawesi and Sunda Strait Table 1). Several specific haplotypes were found within different populations. Composite haplotypes $A A B$, $A B B, B B A$ were found limited to Belitung population, while composite haplotypes of $C A B, B A B$, and CBA were found only in South Sulawesi, Bali, and Sunda Strait, respectively.

Genetic variation observed in these five populations of pearl oyster was expected to be related with environmental characteristics and evolutionary mechanisms in order to maintain survival and reproduction. Intrapopulation genetic variation differences are affected by differences in geographic location, salinity and temperature (Koehn et al., 1976; Koehn et al., 1984) as well as migration, selection and genetic drift (Frankham et al., 2002).

The highest genetic variation was found in South Sulawesi population (0.1939). This appeared to be associated with the presence of specific haplotypes composite CAB (20\%) which was absence in the other populations. Composite haplotypes of BAA (10\%) and CAA $(10 \%)$ that were found in the Sumbawa and Sunda Strait were also found in South Sulawesi population (Figure 1). The presence of common haplotype within these three locations was expected to be associated with the current patterns, namely west and east monsoons flowing around the waters from which the samples were procured. Additionally, larval planktonic stage which lasts for 20-22 days (Haws \& Ellis, 1998) may also contribute to the mixing of individuals originated from different populations. Blanc et al. (1996) reported that intraspecific variation as well as interpopulation differences in pearl oyster populations were influenced by spatial distribution factors. This was allowed due to biphasic nature of oyster life cycle (planktonic and benthic phases) as well as migration and selection during adaptation processes.

It was also reported that oyster seeds living in marine environment during planktonic stage could easily be dispersed by current. For instance, larval oyster of the genus Crassostrea in the Gulf stream owing current velocity of $2 \mathrm{~m} / \mathrm{sec}$. could be dispersed up to 1000- $1300 \mathrm{~km}$ away from their original location (Stenzel, 1971). The occurrence of several haplotypes (AAA and ABA) found with in the populations of Sumbawa and Bali was expected to be associated with geographic proximity and seed exchange by aquaculturists.

Genetic variation which was expressed in both the number of haplotype and haplotype diversity observed in this study was lower compared to those observed by Benzie et al.

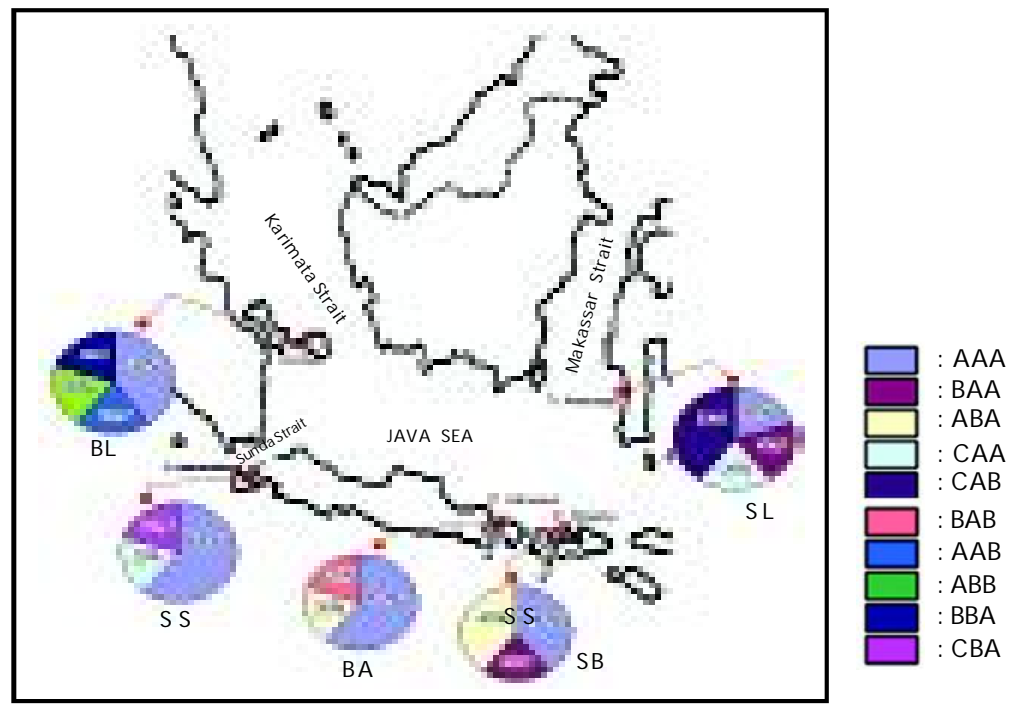

Remarks:

SB: Sumbawa, BA: Bali, SS: Sunda Strait; BL: Belitung, and SL: South Sulawesi

Figure 1. Pie diagrams distribution of frequency and composite haplotype within each of five populations Pinctada maxima 
(2003). Working on Indonesian and Australian populations of P. maxima, he found a total of 11 composite haplotypes in which 3 to 6 haplotypes were present in each population and haplotype diversity ranged from 0.129 0.582 . In other study with P. margaritifera, Susilowati et al. (2008) found a total of $18 \mathrm{com}$ posite haplotypes, with the number of haplotype and haplotype diversity of each population were 3- 8 and 0.105-0.328, respectively. The low level of genetic variation observed within this pearl oyster species might be caused by inadvertent interbreeding resulted from the mating between the escaped hatchery stocks and wild population. This is possible due to the advancement of aquaculture practices of this species. Sofia et al. (2006) explained that genetic variation represented raw material for populations to be capable of adapting to the changing environment. Based on the analysis of genetic equilibrium (not shown), it was found that the $p$-value ranged from $0.000-0.0016$ meaning that the populations were in equilibrium.

Phylogenetic analysis as shown by the UPGMA dendrogram shows that the populations are clustered into two groups (Table 2 and Figure 2). The first group consists of oyster populations of Belitung, Sunda Strait, Bali and Sumbawa while the second group consists of South Sulawesi alone. Genetic differences between South Sulawesi and the rest of the populations seem to be characterized by the presence of specific haplotype CAB (20\%) (Table 1).

Table 2. Nei's genetic distance among five Indonesian populations of pearl oyster (Pinctada maxima)

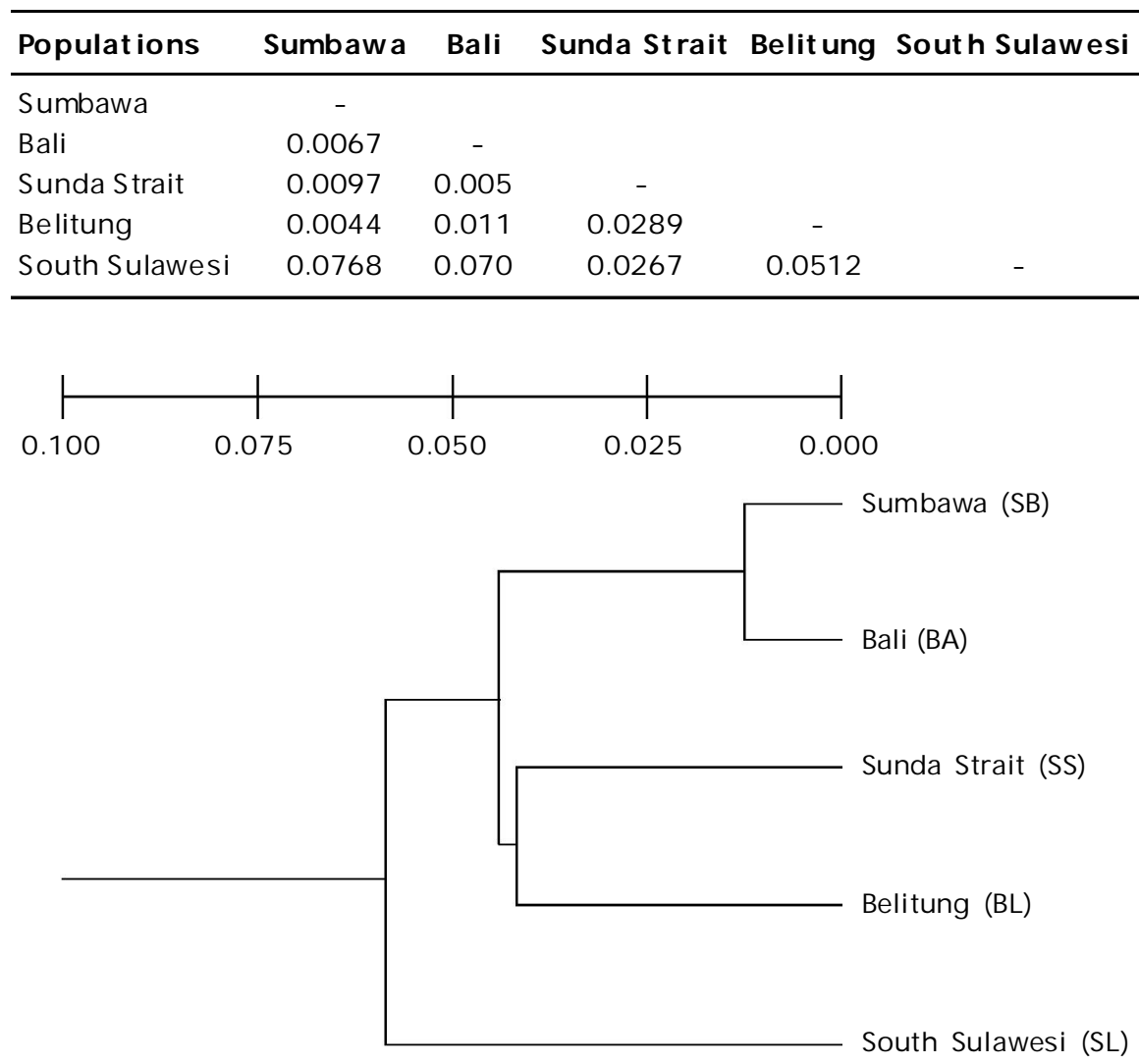

Figure 2. Dendrogram of phylogenetic relationship among five Indonesian populations of pearl oyster (Pinctada maxima) constructed using UPGMA method 


\section{CONCLUSION}

1. Haplotype diversity of Indonesian pearl oyster populations ranged from 0.0970.1939 ; with the highest was found in South Sulawesi (0.1939) and the lowest was found in Sumbawa population (0.097).

2. Phylogeny of five Indonesian pearl oysters (P. maxima), the populations consist of two major groups, in which Belitung, Sunda strait, Bali and Sumbawa formed one group while South Sulawesi formed another group.

\section{FURTHER RESEARCH}

1. Interpopulation hybridization based on geographic considerations can be conducted to increase genetic diversity for broodstock management purposes.

2. Further analysis using more powerful DNA analysis tools, such as DNA sequencing, can be conducted to get more accurate picture.

3. More sampling sites, particularly those of the eastern Indonesian representatives, should be incorporated, to provide more inclusive and clearer view on the population genetics of Indonesian pearl oyster.

\section{REFERENCES}

Appleyard, S.A. \& Ward, R.D. 2006. Genetic diversity and effective population size in mass selection lines of Pacific oyster (Crassostrea gigas). Aquaculture, 254: 148159.

Benzie, J.A.H., Smith, C., \& Sugama, K. 2003. Mitochondrial DNA reveals genetic differentiation between Australian and Indonesian pearl oyster, Pinctada maxima (Jameson 1901) populations. Journal of Shellfish Research, 22: 781- 787.

Bermingham, E. 1990. Mitochondrial DNA and the analysis of fish population structure, In D. Whitmore, ed. Electrophoretic and isoelectric focusing techniques in fisheries management. CRC Press, Boca Ratton, Florida, p. 107- 129.

Blanc, F., Bonhomme, M., Monterforte, C., \& Campanini. 1996. Genetic divergence between black-lipped pearls oyster, Pinctada margaritifera, and $P$. mazatlanica populations. The 8th International Coral Reef Symposium, 118 pp.

Elliott, N.G. 2000. Genetic improvement programmes in abalone: what is the future? Aquaculture Research, 31: 51-59.

Frankham, R., Ballou, J.D., \& Briscoe, D.A. 2002. Introduction to conservation genetics. Cambridge University Press.

Hansen, M.M., Mensberg, K.- L.D., Rasmussen, G., \& Simonsen, V.. 1997. Genetic variation within and among Danish brown trout (Salmo trutta L.) hatchery strains, assessed by PCR- RFLP analysis of mitochondrial DNA segments. Aquaculture, 153: 15- 29.

Haws, M. \& Ellis, S. 1998. Collecting Black-lip pearl oyster spat. Center for Tropical and Subtropical Aquaculture, Honolulu, Hawaii.

Koehn, R.K., Milkman, R., \& J.B. Mitton. 1976. Population genetics of marine pelecypods. IV. Selection, migration and genetic differentiation in the blue mussel, Mytilus edulis. Evolution, 30: 2- 32.

Koehn, R.K., Hall, J.G., Innes, D.J., \& Zera, A.J. 1984. Genetic differentiation of Mytilus edulis in eastern North America. Marine biology, 79: 117- 126.

Nei, M. 1987. Molecular evolutionary genetics Columbia Univ Pr, New York.

Reynolds, J., Weir, B.S., \& Cockerham, C.C. 1983. Estimation of the coancestry coefficient: Basis for a short- term genetic distance. Genetics, 105: 767- 779.

Sofia, S.H., Silva, C.R.M., Galindo, B.A., Almeida, F.S., Sodre, L.M.K., \&Martinez, C.B.R. 2006. Population genetic structure of Astyanax scabripinnis (Teleostei, Characidae) from an urban stream. Hydrobiologia, 553: 245254.

Stenzel, H.B. 1971. Oysters In K.C. Moore, ed. Treatise on Invertebrate Paleontology Part 3: Mollusca. Geol. Soc. Amer and University Kansas, p. 935- 1224.

Susilowati, R., Sumantadinata, K., Soelistyowati, D.T., \& Sudradjat, A. 2008. Karakteristik Genetik Populasi Tiram Mutiara (Pinctada margaritifera) Terkait dengan Distribusi Geografisnya di Perairan Indonesia The Second National Symposium of Aquaculture Biotehcnology, IPB International Conference Center.

Tave, D. 1986. Genetic for fish hatchery managers. 2 ed. The AVI Publishing Company, New York.

Williams, S.T. \& Benzie, J.A.H. 1997. Indo- West Pacific patterns of genetic differentiation in the high- dispersal starfish, Linckia laevigata. Molecular Ecology, 6: 559- 573. 